\title{
ANALISIS KEBUTUHAN BELAJAR UNTUK MENYUSUN PERANGKAT PEMBELAJARAN BIPA TINGKAT PEMULA YANG BERORIENTASI AMERICAN COUNCIL FOR TEACHING FOREIGN LANGUAGE (ACTFL)
}

\author{
Azza Aulia Ramadhani \\ Program Studi Pendidikan Bahasa dan Sastra Indonesia \\ IKIP Budi Utomo Malang, \\ Jalan Citandui 46 Malang \\ Email. azzauliaramadhani@gmail.com
}

\begin{abstract}
This study aims to obtain an objective description of the results of learniing needs analysis for BIPA's learners at beginner level to arrange learning tools. This research uses qualitative design with descriptive approach. The data of this research are words and documents which are then analyzed. Based on the results of the analysis obtained conclusions, namely the results of learning needs analysis BIPA's students at beginner level.
\end{abstract}

Keywods: need analysis, learning tool, BIPA, ACTFL

Keberadaan bahasa Indonesia untuk penutur asing (BIPA) bukan merupakan fakta baru. Sejak zaman penjajahan Belanda, bahkan bahasa Indonesia telah dipelajari oleh orang asing. Bahkan, jauh sebelum itu, bangsa Indonesia mulai dikenal dan wilayah Indonesia mulai menjadi sasaran kunjungan orang-orang asing, bahasa Indonesia sudah dikenal dan dipelajari oleh mereka (Suyitno, 2004). Seiring dengan perkembangan jaman, pengajaran BIPA di Indonesia memiliki peranan yang sangat penting terkait dengan posisi Indonesia dalam percaturan dunia yang semakin hari semakin penting pula. Apalagi dengan akan dibukanya pasar bebas di ASEAN, pada masa yang akan datang hal ini akan memperbesar peluang bagi orang asing untuk memasuki berbagai wilayah di Indonesia. Hal ini yang menyebabkan orang asing harus belajar bahasa Indonesia agar dapat berkomunikasi lebih baik dengan pejabat, teman sejawat, ataupun masyarakat umum di Indonesia. Dengan demikian, kondisi tersebut menuntut lebih banyak lagi kebutuhan program pengajaran BIPA.

Berkaitan dengan pentingnya program pengajaran BIPA di Indonesia, yang perlu pendapat perhatian adalah pelaksanaan pengajarannya. Hingga saat ini belum tersedia kurikulum pembelajaran BIPA yang disusun oleh lembaga pembelajaran bahasa Indonesia untuk penutur asing. Oleh karena itu, dibutuhkan kurikulum atau perangkat pembelajaran yang memenuhi standar dan kebutuhan belajar orang asing, sehingga tidak perlu mengadaptasi standar pembelajaran bahasa asing yang disusun oleh lembaga pembelajaran bahasa asing Eropa, Amerika, ataupun Australia. Selain itu, diperlukan perangkat pembelajaran yang mampu menggiring pembelajaran bahasa Indonesia untuk penutur asing berjalan lebih efektif. Mengingat setiap orang asing yang datang untuk belajar bahasa Indonesia memiliki tujuan yang berbeda sehingga kebutuhan belajar pun menjadi berbeda.

Bila dilihat dari kondisi pelajarnya, pengajaran BIPA di Indonesia memliki karakteristik yang berbeda dengan pengajaran bahasa Indonesia pada umumnya. Pelajar BIPA adalah pelajar asing yang memiliki latar belakang budaya yang berbeda dengan budaya bahasa yang dipelejarinya. Selain itu, kebanyakan pelajar BIPA di Indonesia adalah pelajar dewasa. Sesuai dengan kenyataan tersebut, Wojowasito (dalam Suyitno, 2004) menjelaskan bahwa perbedaan terpenting antara pengajaran BIPA dengan pengajaran bahasa Indonesia pada umumnya adalah (1) BIPA tidak mengintegrasikan anak ke dalam lingkungannya, (2) BIPA hampir dipelajari pada usia dewasa atau pada ketika seseorang telah menguasai sejumlah struktur dari bahasa pertamanya, dan (3) BIPA diolah diluar sistemnya sendiri, dari sistem yang biasanya berbeda.

Richards (2001) mengemukakan bahwa salah satu asumsi dasar dari pengembangan kurikulum adalah program pendidikan yang 
dilaksanakan harus didasarkan pada analisis kebutuhan belajar pelajar. Prosedur ini bermanfaat untuk mengumpulkan informasi tentang kebutuhan pelajar. Hal ini berkaitan dengan pembelajaran bahasa tidak lepas dari keterampilan berbahasa yang dimiliki seseorang. Seperti pembelajaran bahasa pada umumnya, program BIPA mempunyai empat keterampilan berbahasa dalam pelajarannya yang terdiri atas empat komponen, yaitu (a) keterampilan menyimak atau listening skill, (b) keterampilan berbicara atau speaking skill, (c) keterampulan membaca atau read-ing skill, dan (d) keterampilan menulis atau writing skill. Keterampilan menyimak atau listening skill dan keterampilan membaca atau reading skill termasuk dalam keterampilan reseptif, sedangkan keterampilan berbicara atau speaking skill dan keterampilan menulis atau writing skill termasuk dalam keterampilan produktif. Baik belajar bahasa untuk tujuan khusus (BIPA) maupun belajar bahasa Indonesia untuk tujuan umum, bagi pelajar bahasa Indonesia digunakan sebagai alat. Bahasa Indonesia difungsikan sebagai alat komunikasi baik secara lisan maupun tulis. Oleh karena itu, dalam pembelajaran BIPA, tujuan yang ingin dicapai adalah kemampuan pelajar untuk berkomunikasi dengan menggunakan bahasa Indonesia yang dipelajarinya. Dengan demikian, pelajar diharapkan dapat memiliki kemampuan komunikatif. Berdasarkan alasan tersebutlah, perangkat pembelajaran yang akan dikembangkan hanya fokus pada pembelajaran menulis dan berbicara.

Perangkat pembelajaran yang dikembangkan berpedoman pada korespondensi skala kemahiran American Council for Teaching Foreign Language (ACTFL). Peneliti memilih pedoman American Council for Teaching Foreign Language (ACTFL) karena ada beberapa keunggulan yang dimiliki oleh ACTFL dan tidak dimiliki oleh korespondensi skala kemahiran lain. Salah satu keunggulan ACFTL yang paling menonjol adalah pengklasifikasian kemampuan berbahasa pelajar berdasarkan empat keterampilan berbahasa. Keunggulan ini tidak dimiliki oleh skala korespondensi skala kemahiran berbahasa yang lain, misalnya, The Common European of Reference for Languages (CEFR). Selain itu, pelevelan yang terdapat dalam American Council for Teaching Foreign Language (ACTFL) lebih rinci karena ada 11 level, yaitu native, distinguished, superior, advance plus, advance, intermediate high, intermediate mid, intermediate low, novice high, novice mid, dan novice low. Maka, tujuan dari penelitian ini adalah untuk mendeskripsikan hasil analisis kebutuhan belajar dan disesuaikan dengan pedoman kemahiran berbahasa American Council for Teaching Foreign Language (ACTFL) untuk menyusun perangkat pembelajaran BIPA tingkat pemula.

\section{METODE}

Penelitian Perangkat Pembelajaran BIPA Tingkat Pemula yang Berorientasi American Council for Teaching Foreign Language (ACTFL) ini merupakan jenis penelitian kualitatif. Pendekatan kualitatif dalam penelitian ini didasarkan dua pertimbangan. Pertama, penelitian ini bersifat induktif, yaitu pengembangan kon-sep didasarkan data yang ada. Kedua, penelitian ini bersifat deskriptif, artinya penelitian berusaha membuat deskripsi secara sistematis, faktual dan akurat mengenai fakta-fakta, sifat-sifat, serta hubungan antar fenomena yang diselidiki. Hal tersebut sejalan dengan pendapat Hasan (1990:16) yang menyatakan bahwa penelitian kualitatif selalu bersifat deskriptif, artinya data yang dianalisis dan hasil analisisnya berbentuk deskripsi fenomena, tidak berupa angka-angka atau koefisien tentang hubungan antarvariabel. Oleh karena itu, instrumen penelitian dalam penelitian ini adalah peneliti sendiri yakni, peneliti sendiri yang berperan sebagai observer dan sekaligus penganalisis data.

Data dalam penelitian ini berupa skala kemahiran belajar bahasa American Council for Teaching Foreign Language (ACTFL) dan hasil observasi yang diperoleh melalui wawancara. Data yang hasil wawancara ini dideskripsikan untuk menghasilkan sebuah kesimpulan. Berdasarkan data tersebut, sumber data dalam penelitian ini adalah pedoman pelevelan ACTFL dan hasil wawancara dengan pengajar BIPA. Instrumen yang digunakan dalam penelitian ini adalah peneliti sendiri sebagai instrumen kunci. Selain itu, peneliti juga menggunakan instrumen pembantu yang berupa pedoman wawancara.

\section{HASIL}

Berdasarkan wawancara yang dilakukan pada pengajar BIPA, ditemukan beberapa 
permasalahan. Permasalahan ini berkaitan dengan keterampilan yang akan diajarkan dan dilatihkan serta beberapa materi yang dirasa sulit disampaikan oleh guru. Wawancara ini dilakukan dengan menggunakan pedoman wawancara kepada guru.

Pembelajaran bahasa tidak lepas dari keterampilan berbahasa yang dimiliki seseorang. Tidak berbeda pembelajaran bahasa pada umumnya, program BIPA mempunyai empat keterampilan berbahasa dalam pelajarannya yang terdiri atas empat komponen, yaitu (a) keterampilan menyimak atau listening skill, (b) keterampilan berbicara atau speaking skill, (c) keterampulan membaca atau read-ing skill, dan (d) keterampilan menulis atau writing skill. Keterampilan menyimak atau listening skill dan keterampilan membaca atau reading skill termasuk dalam keterampilan reseptif, sedangkan keterampilan berbicara atau speaking skill dan keterampilan menulis atau writing skill termasuk dalam keterampilan produktif. Baik belajar bahasa untuk tujuan khusus (BIPA) maupun belajar bahasa Indonesia untuk tujuan umum, bagi pelajar bahasa Indonesia digunakan sebagai alat. Bahasa Indonesia difungsikan sebagai alat komunikasi baik secara lisan maupun tulis. Oleh karena itu, dalam pembelajaran BIPA, tujuan yang ingin dicapai adalah kemampuan pelajar untuk berkomunikasi dengan menggunakan bahasa Indonesia yang dipelajarinya. Dengan demikian, pelajar diharapkan dapat memiliki kemampuan komunikatif. Berdasarkan alasan tersebutlah, perangkat pembelajaran yang akan dikembangkan hanya fokus pada pembelajaran menulis dan berbicara.

Baik belajar bahasa untuk tujuan khusus (BIPA) maupun belajar bahasa Indonesia untuk tujuan umum, bagi pelajar bahasa Indonesia digunakan sebagai alat. Bahasa Indonesia difungsikan sebagai alat komunikasi baik secara lisan maupun tulis. Oleh karena itu, dalam pembelajan BIPA, tujuan yang ingin dicapai adalah kemampuan pelajar untuk berkomunikasi dengan menggunakan bahasa Indonesia yang dipelajarinya. Dengan demikian, pelajar diharapkan dapat memiliki kemampuan komunikatif (Suyitno, 2004). Berdasarkan tujuan komunikatif itulah, guru menggunakan metode celup total dalam mengajarkan bahasa Indonesia pada penutur asing. Metode celup total yang dimaksud adalah guru menggunakan bahasa Indonesia saja sebagai bahasa pengantar di kelas. Guru berupaya tidak menggunakan bahasa Inggris dalam menyampaikan materi. Hal tersebut dilakukan agar pelajar asing terbiasa dan semakin cepat lancar dalam berbahasa Indonesia. Namun, kendala yang dialami guru adalah ketika siswa tidak memahami materi yang disampaikan dan guru pun terkadang kesulitan dalam menjawab pertanyaan pelajar asing dengan kalimat bahasa Indonesia yang sederhana apabila pelajar yang dihadapi adalah pelajar pemula.

\section{PEMBAHASAN}

\section{Pembelajaran BIPA Tingkat Pemula}

Guru menggunakan metode celup total dalam mengajar. Hal ini dilakukan agar tujuan komunikatif dapat tercapai sesuai dengan waktu yang telah ditentukan. Hal tersebut sesuai dengan pendapat Suyitno (2004) yang menjelaskan bahwa dalam kaitannya dengan teknik pembelajaran BIPA, ada beberapa hal yang dikaji, yaitu (1) teknik penyampaian materi, (2) teknik menghadapi pelajar, dan (3) teknik penciptaan suasana belajar. Teknik penyampaian materi dibagi dalam 3 tahap, yakni teknik membuka pelajaran, teknik menyampaikan materi baru, dan teknik menutup pelajaran. Teknik yang digunakan oleh guru dalam menyampaikan materi pada dasarnya menggunakan teknik celup total. Guru berusaha sedapat mungkin tidak menggunakan bahasa Inggris. Berbagai cara yang digunakan untuk penyajian materi tersebut diantaranya adalah cara tanya jawab, pelatihan, penugasan, demostrasi, pemberian konsultasi baik kelompok maupun individual, tutorial, penubian (drill), dan koreksi.

Dalam pembelajaran BIPA di Indonesia, ancangan komunikatif sangat mungkin untuk dapat diterapkan, karena BIPA diajarkan ditempat bahasa tersebut digunakan. Ada beberapa keuntungan yang diperoleh apabila BIPA diajarkan di lingkungan penutut asli, yakni (1) bahan-bahan otentik tidak terlalu sulit diperoleh, misalnya dari brosur, TV, surat kabar, dan lain-lain; (2) kegiatan di kelas dapat dihubungkan dengan tugas di luar kelas atau tugas terstruktur yang lain; (3) pemahaman dan 
pengalaman dalam hubungan bahasa dan budaya menjadi lebih konkret; dan (4) masalah gegar budaya yang dialami pelajar dapat diatasi dengan membina hubungan yang baik antara pelajar, pengajar dan masyarakat (Sutiyono dalam Suyitno, 2004).

Pengembangan materi membaca dan menulis disesuaikan dengan tingkat kemampuan pelajarnya. Untuk tingkat pemula diberikan bacaan dalam bahasa Indonesia yang agak kompleks, dan untuk tingkat lanjut diberikan bacaan bahasa Indonesia yang kompleks. Materimateri bacaan sederhama banyak diambilkan dari bacaan yang ada di majalah anak-anak, bacaan yang ada pada buku dasar, atau bacaan yang disusun sendiri oleh pengajar. Adapun untuk materi menulis dimulai dari menulis kalimat, menulis topik sederhana tentang pengalaman pribadi pelajar, atau apa yang telah dilakukannya sampai dengan menulis makalah untuk diseminarkan dalam seminar di kelasnya.

Sejalan dengan uraian tentang kompetensi komunikatif di atas, lebih lanjut Hymes (1971) menjelaskan bahwa agar seseorang dapat berkomunikasi secara efektif dalam suatu bahasa, ia memerlukan pengetahuan berikut, yakni (1) pengetahuan tentang bentuk bahasa yang mungkin dikatakan, (2) pengetahuan tentang kata yang dapat dituturkan dan dapat dipahami oleh pendengar, (3) pengetahuan tentang kata yang sesuai dan lazim menurut konteksnya, dan (4) pengetahuan tentang kata yang pernah diujarkan orang. Dengan penguasaan keempat hal tersebut seseorang dapat berbahasa secara berterima.

\section{Analisis Kebutuhan Belajar Pelajar BIPA Tingkat Pemula}

Richards (2001) mengemukakan bahwa salah satu asumsi dasar dari pengembangan kurikulum adalah program pendidikan yang dilaksanakan harus didasarkan pada analisis kebutuhan belajar pelajar. Prosedur ini bermanfaat untuk mengumpulkan informasi tentang kebutuhan pelajar. Oleh karena itu, sebelum memulai mengembangkan perangkat pembelajaran BIPA, perlu dilakukan analisis kebutuhan belajar pelajar asing. Analisis kebutuhan belajar yang dilakukan bertujuan untuk mengetahui alasan dan tujuan mereka dalam mempelajari bahasa Indonesia. Hal ini mempengaruhi pemilihan materi yang disajikan dalam silabus. Selain itu, latar belakang budaya pelajar juga turut mempengaruhi materi yang akan disajikan, mengingat setiap pelajar dari negara yang berbeda akan memiliki kebiasaan belajar yang berbeda pula sehingga hal tersebut berpengaruh terhadap pemilihan metode pembelajaran yang dilaksanakan di dalam kelas. Hal tersebut sesuai dengan hasil penelitian yang telah dilakukan oleh Deneme (2010) yang mengungkapkan bahwa latar belakang budaya turut mempengaruhi pilihan strategi pembelajaran yang digunakan di dalam kelas. Selain itu, orang-orang dari budaya yang berbeda akan belajar dengan cara yang berbeda pula. Mahasiswa Yordania, misalnya, sering menggunakan metode hafalan dalam belajar. Tidak terkecuali dalam belajar bahasa. Mahasiswa Yordania berulang kali mengucapkan atau menulis kata-kata bahasa Inggris yang baru diberikan oleh guru. Hal tersebut berbeda dengan cara belajar mahasiswa Turki dan juga mahasiswa Spanyol. Mahasiswa Spanyol lebih sering dilatih menulis untuk mengasah kemampuan berbahasa Inggris mereka. Mahasiswa tidak hanya dilatih untuk menulis secara formal, tetapi juga dilatih menulis catatan harian. Hal tersebut dilakukan agar mahasiswa tidak hanya memahami teori, tetapi juga mempraktikkannya dalam kehidupan sehari-hari agar pembelajarab yang telah dilakukan lebih bermanfaat. Metode menulis catatan harian juga digunakan dalam pembelajaran bahasa Indonesia untuk penutur asing (BIPA). Catatan harian yang ditulis mahasiswa berbentuk jurnal yang digunakan untuk memantau perkembangan kemampuan berbahasa Indonesia si pelajar asing.

Pembelajaran bahasa tidak lepas dari keterampilan berbahasa yang dimiliki seseorang. Seperti pembelajaran bahasa pada umumnya, program BIPA mempunyai empat keterampilan berbahasa dalam pelajarannya yang terdiri atas empat komponen, yaitu (a) keterampilan menyimak atau listening skill, (b) keterampilan berbicara atau speaking skill, (c) keterampulan membaca atau read-ing skill, dan (d) keterampilan menulis atau writing skill. Keterampilan menyimak atau listening skill dan keterampilan membaca atau reading skill termasuk dalam keterampilan reseptif, sedangkan keterampilan 
berbicara atau speaking skill dan keterampilan menulis atau writing skill termasuk dalam keterampilan produktif. Baik belajar bahasa untuk tujuan khusus (BIPA) maupun belajar bahasa Indonesia untuk tujuan umum, bagi pelajar bahasa Indonesia digunakan sebagai alat. Bahasa Indonesia difungsikan sebagai alat komunikasi baik secara lisan maupun tulis. Oleh karena itu, dalam pembelajaran BIPA, tujuan yang ingin dicapai adalah kemampuan pelajar untuk berkomunikasi dengan menggunakan bahasa Indonesia yang dipelajarinya. Dengan demikian, pelajar diharapkan dapat memiliki kemampuan komunikatif. Berdasarkan alasan tersebutlah, perangkat pembelajaran yang akan dikembangkan hanya fokus pada pembelajaran menulis dan berbicara.

Perangkat pembelajaran yang dikembangkan berpedoman pada korespondensi skala kemahiran American Council for Teaching Foreign Language (ACTFL). Bagan berikut memberikan hubungan antara tingkatan dari ACTFL dan skala kemahiran ILR.

Tabel 1 Bagan Perbandingan

\begin{tabular}{|c|c|c|}
\hline $\begin{array}{l}\text { Skala } \\
\text { ILR }\end{array}$ & Skala ACTFL & Definisi \\
\hline 5 & Native & $\begin{array}{l}\text { Mampu berbicara seperti penutur asli } \\
\text { yang berpendidikan }\end{array}$ \\
\hline $4+$ & Distinguished & $\begin{array}{l}\text { Mampu berbicara dengan kelancaran, } \\
\text { ketepatan tatabahasa, ketelitian kosakata } \\
\text { dan idiomatik yang baik. }\end{array}$ \\
\hline $3+$ & Superior & $\begin{array}{l}\text { Mampu menggunakan suatu bahasa } \\
\text { dengan akurasi struktu r dan kosakata } \\
\text { yang memadai untuk berpartisipasi secara } \\
\text { efektif dalam percakapan pada } \\
\text { lingkungan formal dan informal. }\end{array}$ \\
\hline $2+$ & Advance Plus & $\begin{array}{l}\text { Mampu memenuhi sebagian besar } \\
\text { persyaratan pekerjaan dan menunjukkan } \\
\text { beberapa kemampuan untuk } \\
\text { berkomunikasi pada topik -topik yang } \\
\text { konkrit. }\end{array}$ \\
\hline 2 & Advance & $\begin{array}{l}\text { Mampu memenuhi tuntutan sosial rutin } \\
\text { dan persyaratan kerja yang terbatas. }\end{array}$ \\
\hline $1+$ & Intermediate - High & $\begin{array}{l}\text { Mampu memenuhi sebagian besar } \\
\text { kebutuhan dasar untuk bertahan hidup } \\
\text { dan tuntutan sosial yang terbatas. }\end{array}$ \\
\hline 1 & $\begin{array}{l}\text { Intermediate - Mid } \\
\text { Intermediate - Low }\end{array}$ & $\begin{array}{l}\text { Mampu memenuhi beberapa kebutuhan } \\
\text { dasar untuk hidup dan beberapa tuntutan } \\
\text { sosial yang terbatas. } \\
\text { Mampu memenuhi kebutuhan dasar } \\
\text { untuk bertahan hidup dan persyaratan } \\
\text { minimum kesopanan }\end{array}$ \\
\hline $0+$ & Novice - High & $\begin{array}{l}\text { Mampu memenuhi kebutuhan yang } \\
\text { mendesak dengan tuturan yang dipelajari. }\end{array}$ \\
\hline 0 & $\begin{array}{l}\text { Novice - Mid } \\
\text { Novice - Low } \\
0\end{array}$ & $\begin{array}{l}\text { Hanya mampu menggunakan bahasa } \\
\text { dalam kapasitas yang terbatas. } \\
\text { Tidak dapat berbicara dalam bahasa lisan. } \\
\text { Tidak memiliki kemampuan apapun } \\
\text { dalam bahasa. }\end{array}$ \\
\hline
\end{tabular}


Berikut adalah rincian kemampuan yang dimiliki oleh pembelajar tingkat pemula berdasarkan pedoman ACTFL.

1) Pedoman ACTFL: Mendengarkan Novice

a) Novice-Low

Pemahaman terbatas pada kata-kata yang terisolasi, seperti cognate (bahasa yang sama asalnya), borrowing words (kata-kata pinjaman), dan kaidah-kaidah sosial kemasyarakatan yang umum digunakan. Pada dasarnya tidak mempunyai kemampuan untuk memahami bukan untuk ucapan-ucapan pendek sekalipun.

b) Novice-Mid

Mampu memahami beberapa ujaranujaran pendek yang dipelajari, terutama saat konteks mendukung pemahaman dengan kuat dan berbicaranya terdengar dengan jelas. Memahami beberapa kata dan frasa dari pertanyaan sederhana, pernyataan, perintah yang sering digunakan dan formula kesopanan tentang topik yang merujuk pada informasi pribadi atau situasi fisik langsung. Pendengar memerlukan jeda waktu yang panjang untuk memahami ujaran dan secara berkala meminta pengulangan dan/atau meminta memperlambat kecepatan berbicara.

c) Novice-High

Mampu memahami ujaran-ujaran pendek yang dipelajari dan beberapa ujaran kalimat-kalimat panjang, khususnya saat konteks mendukung pemahaman dengan sangat kuat dan berbicaranya terdengar dengan jelas. Memahami kata dan frasa dari pertanyaan sederhana, pernyataan, perintah-perintah yang sering digunakan, dan formula kesopanan. Mungkin memerlukan pengulangan, mengulang, dan/atau melambatkan kecepatan berbicara untuk tujuan pemahaman.

2) Pedoman ACTFL: Berbicara - Novice

Deskripsi Umum

Tingkatan Novice dicirikan oleh kemampuan untuk berkomunikasi yang paling tidak dengan metri yang telah dipelajari.

a) Novice-Low
Produksi lisan terdiri atas kata-kata yang terisolasi dan mungkin beberapa frase yang umum digunakan. Pada dasarnya tidak memiliki kemampuan komunikatif fungsional.

b) Novice-Mid

Meskipun kuantitasnya ditingkatkan, produksi lisan terdiri atas kata-kata yang terisolasi dan frase yang dipelajari dalam wilayah kebutuhan yang telah diprediksi sebelumnya. Kosakata hanya cukup untuk menangani kebutuhan dasar, sederhana untuk mengekspresikan nilainilai kesopanan dasar. Jarang sekali terjadi ujaran yang terdiri atas atau lebih dari dua atau tiga kata dan sering menunjukkan jeda yang panjang dan pengulangan kata-kata dari lawan bicara. Pembicara mungkin memiliki beberapa kesulitan menghasilkan bahkan pada ucapan-ucapan sederhana sekalipun. Membutuhkan usaha yang besar dalam memahami ujaran atau ucapan dari siswa pada tingkat ini.

c) Novice-High

Mampu memenuhi sebagian persyaratan dari pertukaran komunikatif dasar dengan bergantung pada tuturan yang telah dipelajari tetapi kadang-kadang memperluas komunikasi tersebut melalui rekombinasi sederhana unsur-unsurnya. Bisa bertanya atau membuat pernyataan sesuai dengan materi yang telah dipelajari. Menunjukkan tanda-tanda spontanitas walaupun hanya sedikit ekspresi mereka yang sesuai dengan konteks yang sesungguhnya. Pembicaraan hanya terdiri atas ujaranujaran yang telah dipelajari yang disesuaikan dengan situasi tertentu. Kosakata berpusat pada bidang-bidang seperti objek-objek dasar, tempat, dan istilah kekerabatan yang paling umum. Pengucapan mungkin masih sangat dipengaruhi oleh bahasa pertama. Kesalahan sering terjadi. Di samping dengan melakukan pengulangan pengucapan, penutur pada tingkat Novice-high akan sulit dipahami bahkan oleh lawan bicara yang memperhatikannya.

3) Pedoman ACTFL: Membaca - Novice 
a) Novice-Low

Sesekali bisa mengidentifikasi kata-kata terisolasi dan/atau frase utama saat didukung oleh konteks yang kuat.

b) Novice-Mid

Mampu mengenali simbol-simbol huruf abjad dan/atau sistem penulisan suku kata dan/atau sejumlah karakter dalam suatu sistem yang menggunakan karakter. Pembaca bisa mengidentifikasi sejumlah peningkatan sejumlah konteks kata dan/atau frasa termasuk cognate (bahasa yang sama asalnya) dan kata-kata pinjaman jika sesuai. Materi yang dipahami jarang melebihi frase tunggal pada satu waktu, dan mungkin diperlukan pengulanagan dalam membaca.

c) Novice-High

Memiliki kontrol yang memadai dari sistem penulisan untuk menafsirkan bahasa tertulis dalam bidang-bidang kebutuhan praktis. Setelah pembaca mempelajari beberapa materi kosakata, mereka bisa membaca untuk tujuan pengarahan dan pembelajaran, pesan standar, frase, atau ekspresi, seperti beberapa pilihan pada menu makanan, jadwal, peta, dan tanda-tanda. Meskipun mereka seringkali tidak konsisten, pembaca pada tingkat Novice-high mungkin bisa memahami makna dari materi yang lebih sulit apabila didukung oleh konteks dan/atau mempunyai latar belakang pengetahuan ekstra linguistik yang bagus.

4) Pedoman ACTFL: Menulis - Novice

a) Novice-Low

Mampu membuat beberapa huruf dalam sebuah sistem abjad. Di dalam bahasa yang tulisannya menggunakan sistem suku kata atau karakter, penulis mampu menyalin dan menghasilkan coretan dasar. Bisa menghasilkan romanisasi karakter tunggal apabila diperlukan.

b) Novice-Mid

Mampu menyalin atau menuliskan katakata atau frasa umum dan memperbanyak beberapa kata atau frase dari memori. Tidak ada kemampuan menulis praktis yang komunikatif. c) Novice-High

Mampu menulis hanya terbatas pada halhal sederhada, ekspresi-ekspresi tetap dan materi dan rekombinasi yang telah dihafalnya. Bisa menyediakan informasi pada dokumen dan bentuk-bentuk yang sederhana. Bisa menulis nama, nomor, tanggal, ekbangsaan sendiri, dna informasi otobiografi sederhana, serta beberapa kalimat sinkat dan daftar sederhana. Bisa menulis semua simbol dalam sistem alfabetis atau suku kata atau 50-100 karakter atau majemuk dalam suatu sistem penulisan karakter. Sebagian besar ejaan dan representasi simbolsimbol (huruf, suku kata, karakter) sudah benar.

Hal-hal yang disa dipahami pada tingkatan Novice, yaitu (1) nama-nama benda; (2) nama-nama makanan dan minuman; (3) katakata untuk tindakan-tindakan umum; (4) salam dan ekspresi-ekspresi yang umum dalam perpisahan; (5) peringatan dan perintah-perintah dasar, seperti Berhenti!, Awas!, dan Hati-hati!; (6) kata-kata dasar yang menggambarkan ukuran, warna, atau usia; dan (7) pertanyaan dan pernyataan sederhana yang menggunakan katakata dari kategori di atas. Kemudian, hal-hal yang bisa dikuasai dalam berbicara pada tingkatan Novice, yaitu (1) menyapa orang dengan sopan; (2) mengucapkan ucapan terima kasih dengan sopan; (3) mengatakan "ya" dan "tidak"; (4) menggunakan frasa yang telah hafal untuk memesan secangkir kopi atau makanan; (5) menghitung sampai 100; (6) mengucapkan selamat tinggal dengan sopan; (7) memberitahukan nama Anda; (8) mengatakan tentang asal-usul dirinya; (9) nama objek-objek konkret, seperti mebel, tanaman, hewan, alatalat, mesin, dan jenis-jenis makanan; (10) nama dari jenis-jenis orang, seperti laki-laki, perempuan, anak laki-laki, gadis, dan bayi; (11) nama warna; dan (12) nama ukuran objek atau umur orang, seperti perahu besar atau anak kecil. Selanjutnya, hal-hal yang bisa dikuasai dalam membaca pada tingkatan Novice, yaitu (1) huruf dalam alphabet atau sistem penulisan suku kata atau beberapa karakter dalam sistem yang menggunakan karakter; (2) menu; (3) jadwal; (4) peta; (5) rambu-rambu jalan; dan (6) tanda-tanda 
di atas toko. Lalu, hal-hal yang bisa dikuasai dalam menulis pada tingkatan Novice; yaitu (1) informasi untuk formulis registrasi hotel; (2) nformasi untuk dokumen perjalanan; (3) ekspresi-ekspresi sederhana; (4) kata atau kalimat yang telah dipelajari; dan (5) tanggal dan nomor.

Pedoman ACTFL menjadi dasar penyusunan silabus dan materi pembelajaran karena di dalam pedoman ACTFL telah dirinci kemampuan pembelajar bahasa asing pada empat aspek keterampilan berbahasa. Selain itu, penyusunan silabus dan materi pembelajaran BIPA untuk tingkat pemula juga didasarkan pada analisis kebutuhan. Tujuan pembelajaran juga sangat menentukan materi yang diajarkan, teks bacaan yang diberikan, teks dialog yang dicontohkan, dan sebagainya.

\section{KESIMPULAN}

Pembelajaran bahasa tidak lepas dari keterampilan berbahasa yang dimiliki seseorang. Seperti pembelajaran bahasa pada umumnya, program BIPA mempunyai empat keterampilan berbahasa dalam pelajarannya yang terdiri atas empat komponen, yaitu (a) keterampilan menyimak atau listening skill, (b) keterampilan berbicara atau speaking skill, (c) keterampulan membaca atau read-ing skill, dan (d) keterampilan menulis atau writing skill. Keterampilan menyimak atau listening skill dan keterampilan membaca atau reading skill termasuk dalam keterampilan reseptif, sedangkan keterampilan berbicara atau speaking skill dan keterampilan menulis atau writing skill termasuk dalam keterampilan produktif. Baik belajar bahasa untuk tujuan khusus (BIPA) maupun belajar bahasa Indonesia untuk tujuan umum, bagi pelajar bahasa Indonesia digunakan sebagai alat. Bahasa Indonesia difungsikan sebagai alat komunikasi baik secara lisan maupun tulis. Oleh karena itu, dalam pembelajaran BIPA, tujuan yang ingin dicapai adalah kemampuan pelajar untuk berkomunikasi dengan menggunakan bahasa Indonesia yang dipelajarinya. Dengan demikian, pelajar diharapkan dapat memiliki kemampuan komunikatif. Berdasarkan alasan tersebutlah, perangkat pembelajaran yang akan dikembangkan hanya fokus pada pembelajaran menulis dan berbicara.
Perangkat pembelajaran yang dikembangkan berpedoman pada korespondensi skala kemahiran American Council for Teaching Foreign Language (ACTFL). Peneliti memilih pedoman American Council for Teaching Foreign Language (ACTFL) karena ada beberapa keunggulan yang dimiliki oleh ACTFL dan tidak dimiliki oleh korespondensi skala kemahiran lain. Salah satu keunggulan ACFTL yang paling menonjol adalah pengklasifikasian kemampuan berbahasa pelajar berdasarkan empat keterampilan berbahasa. Keunggulan ini tidak dimiliki oleh skala korespondensi skala kemahiran berbahasa yang lain, misalnya, The Common European of Reference for Languages (CEFR). Selain itu, pelevelan yang terdapat dalam American Council for Teaching Foreign Language (ACTFL) lebih rinci karena ada 11 level, yaitu native, distinguished, superior, advance plus, advance, intermediate high, intermediate mid, intermediate low, novice high, novice mid, dan novice low. Maka, tujuan dari penelitian ini adalah untuk mendeskripsikan hasil analisis kebutuhan belajar dan disesuaikan dengan pedoman kemahiran berbahasa American Council for Teaching Foreign Language (ACTFL) untuk menyusun perangkat pembelajaran BIPA tingkat pemula.

\section{SARAN}

Berdasarkan rumusan simpulan di atas, saran yang dapat diajukan, yaitu dengan analisis hasil kebutuhan belajar guru dapat memilih dan menyesuaikan materi yang cocok untuk pelajar. Dengan demikian, pembelajaran yang dilaksanakan sesuai dengan tujuan pembelajaran dan akan dapat bermanfaat secara maksimal.

\section{DAFTAR RUJUKAN}

Deneme, S. 2010. Cross-Cultural Differences in Language Learning Strategy Preference: A Comparative Study. The International Journal Language Society and Culture, (Online), 31 (1): 81-89, (www.educ.utas.edu.au/users/tle/ JOURNAL), diakses 1 September 2014. Hasan, M. Z. 1990. Pengembangan Penelitian Kualitatif dalam Bidang Bahasa dan Sastra. Dalam Aminuddin (Eds.), Karakteristik Peniltian Kualitatif (hlm. 12-25). Malang: YA 3. Hymes, D. 1971. On Communicative Competence. Dalam Pride, J.B. dan Holmes, J. 
(Eds), Sosiolinguistics. Middlesex: Penguin Books.

Richard, J.C. 2001. Curriculum Development in Language Teaching. United States of America: Cambridge University Press.
Suyitno, I. 2004. Pengetahuan Dasar BIPA:

Pandangan Teoritis Belajar Bahasa. Yogyakarta: CV. Grafika Indah

Tim ILR. 1986. Skala Korespondensi Kemahiran: American Council for Teaching Foreign Lamguage. USA 
28\| Azza Aulia Ramadhani, Analisis Kebutuhan Belajar ..... 